\title{
Problems of regional grain market development
}

\author{
Farit Mukhametgaliev*, Landysh Sitdikova, Fayaz Avkhadiev, Ilgizar Gainutdinov, and Valentina Petrova
}

Kazan State Agrarian University, Kazan 420015, Russia

\begin{abstract}
The relevance of the study is defined by the need to develop agricultural markets at the regional level in response to new challenges to external economic environment. The purpose of the paper is to develop recommendations on optimization of grain production and sale efficiency on the basis of analysis of the current situation and identification of trends in agricultural development in the regions of Russia. The novelty of the study is to identify trends in the development of the grain market at the regional level and to justify the necessary priority measures to increase the economic efficiency of the grain production industry. The paper presents the analysis of the level of development of the grain market, identifies priority directions to increase the production volume and efficiency of cereal production, recommendations to ensure sustainable growth of revenues from the sale of grain products. The practical significance of research results includes the possibility of using them in the design of programs for the development of regional food markets, organizational and economic, technological measures to increase the efficiency of grain production in farms in order to achieve high targets.
\end{abstract}

\section{Introduction}

The priority task in solving the problem of food supply for the population is effective development of the agricultural market. The implementation of tasks set forth in the Doctrine of Food Security of Russia to a large extent depends on the level of development and effective functioning of grain products, on technological and technical equipment of the grain production industry. The development of the grain market in the country and in its regions is a fundamental condition for efficient functioning of not only agriculture, but also of the entire agro-industrial complex. The solution of the task of the total satisfaction of the population with food mainly depends on the level of development of the grain market. To ensure internal needs of agricultural enterprises, country farms, farms of the population with fodder grain, formation of grain food fund of the country and the export potential in Russia there is a need to create the grain market with at least 100-120 million tons of grain per year [1-3]. Grain and its processing products in food self-sufficiency of the population are of priority importance due to high share of bread products in the food diet of people, its suitability for long-term storage, easy transportability and the possibility of creating a strategic reserve in the form of insurance and reserve funds. The strategic purpose of grain is the possibility of creating reserves for emergency situations such as food for the population, forage for livestock production, raw materials for grain processing and food processing enterprises, as well as a tool for regulating prices in domestic grain market [4-7]. Besides, grain production is the most important source of income and a profitable activity of most agricultural businesses. Therefore, the grain industry of the country and regions is facing the task of meeting the need for grain by not less than $95 \%$ due to domestic grain market [8-11]. This task can be achieved by placing the grain industry to the forefront of potentially export-oriented industry through effective management of grain production, storage and processing technology, improving the relevant organizational and economic conditions, as well as implementing innovative and investment projects. In this regard, it is critical to define trends and identify the main priorities for the development of the grain market and organizational and economic aspects of improving the efficiency of the grain industry.

\section{Materials and methods}

The theoretical and methodological framework of the study is based on the interaction and complementarity of fundamental provisions and the concept of economic theory. The theoretical and methodological basis also included the works of foreign and domestic agricultural economists, normative and legislative acts of the Russian Federation on the regulation of agro-food policy, materials of international and All-Russian scientific and practical conferences devoted to the development of agriculture.

The general methodological framework of the study contains the systemic analysis. The extensive data and the variety of its content led to different approaches, methods and techniques of scientific research of socio-

\footnotetext{
* Corresponding author: fem59@mail.ru
} 
economic processes within the limits of system analysis, such as constructive, deterministic, retrospective, dynamic, statistical.

The study applied methods revealing trends in the development of agro-food policy and features of their manifestation: monographic, abstract-logical, calculation-constructive, economic-statistical, analogy.

Official data of the Federal Service of State Statistics of the Russian Federation, the Ministry of Agriculture of the Russian Federation, the Ministry of Agriculture and Food of the Republic of Tatarstan, planning and reporting documents of agricultural organizations, materials contained in monographs, dissertations and reports of research institutes, publications, materials of scientific conferences, expert assessments, data obtained during author's analysis and calculations were used as the information and factual basis of the study.

\section{Results}

Field husbandry is the main source of crop production both for domestic consumption and for sale on the agricultural market. The volume of livestock production, its quality, successful development of many enterprises of processing industry depends on the level of grain production for fodder and food purposes [12-14].

In order to meet the demand of the food market and to provide the population with bakery products in the amount of 300-350 kg per person, it is accepted to use an enlarged standard of one ton of grain per citizen. Much of the grain is used for feeding in livestock industries, for the production of poultry meat, pigs, cattle and milk. The remaining part of grain, with the exception of certain grain resources of state and municipal needs, forms the export potential [15-17].

The formation of the grain market in the region shall take into account conditions, competition and the development of market infrastructure. The market primarily needs grain products, which have the necessary qualities for bakery and pasta production, i.e. mainly wheat not lower than class 3. Unfortunately, the production of such wheat in 2017 in Russia had a declining tendency. In such conditions, government regulation of export and import of grain of mainly 3 and 4 class and fodder grain is necessary [18-20].
In the regions of the Russian Federation, grain production is a strategic industry. From 2013 to 2020 the Ministry of Agriculture and Food of the Republic of Tatarstan defined grain production as the main direction and forecast a sustainable growth.

Table 1. Grain production in the Republic of Tatarstan, thousand tons

\begin{tabular}{|l|c|c|c|c|c|c|c|c|}
\hline \multirow{2}{*}{ Indicator } & \multicolumn{7}{|c|}{ Years } \\
\cline { 2 - 10 } & 2013 & 2014 & 2015 & 2016 & 2017 & 2018 & 2019 & 2020 \\
\hline $\begin{array}{l}\text { Production of } \\
\text { grain and grain } \\
\text { legume: }\end{array}$ & & & & & & & & \\
- plan & 4300 & 4400 & 4500 & 4600 & 4700 & 4800 & 5000 & 5200 \\
\hline -actual & 2802.8 & 3366.0 & 3367.7 & 4105.2 & 5252 & 3914 & - & - \\
\hline $\begin{array}{l}\text { Plan fulfilment, } \\
\%\end{array}$ & 65.2 & 76.5 & 74.8 & 89.2 & 111.7 & 81.2 & - & - \\
\hline
\end{tabular}

Table 1 shows that the planned indicators for grain production in the republic were mainly fulfilled by only $65-89 \%$, except for 2017, when the plan was accomplished by $111.7 \%$. Agricultural producers of the republic collected 3.9 million tons of grain in 2018, compared to 5.2 million tons last year [21]. The loss of gross grain crop in 2018 was due to the drought in 17 districts out of 43 engaged in grain cultivation in the republic.

The Government of the Russian Federation is committed to ensure the export capacity of agroindustrial complex by 2024 up to $\$ 45$ billion [22]. The main agricultural product that makes up the export capacity of agro-industrial complex is grain. In this regard, this industry shall solve not only the problem of self-sufficiency of grain products, but also of increasing grain production in order to increase the volume of grain supplies for export. For this purpose, it is necessary to increase the competitiveness of the industry and to create conditions for the development of various distribution channels through the formation of an effective system of wholesale and retail, implementation of intervention policies in domestic grain market. The competitiveness of grain products is determined by individual costs of its production, quality, as well as the existing level of demand in the market. The latter are expressed by the market price level and predetermines the efficiency of grain production (Table 2 ).

Table 2. Efficiency of grain production in agricultural organizations of the Republic of Tatarstan

\begin{tabular}{|c|c|c|c|c|c|c|}
\hline \multirow[t]{2}{*}{ Indicator } & \multicolumn{5}{|c|}{ Years } & \multirow{2}{*}{$\begin{array}{c}\text { Deviation, } 2018 \text { to } \\
2014(+,-) \%\end{array}$} \\
\hline & 2014 & 2015 & 2016 & 2017 & 2018 & \\
\hline Grain in weight after processing, thousand tons & 3366.0 & 3367.7 & 4105.2 & 4856.6 & 357.6 & +8.7 \\
\hline Yield capacity, centner per 1 ha & 21.6 & 21.2 & 25.3 & 32.0 & 24.8 & +14.8 \\
\hline Produced per 100 ha of tilled area, c. & 1035 & 1037 & 1265 & 1499 & 1132 & +9.4 \\
\hline Sold, thousand tons & 1549.4 & 1662.5 & 1886.9 & 2035.0 & 2237.2 & +44.4 \\
\hline Marketable value, $\%$ & 46.0 & 49.3 & 45.9 & 41.9 & 61.1 .0 & +15.1 \\
\hline Receipts in cash, mln rub. & 9962.6 & 13083.8 & 15020.3 & 12754.4 & 17674.2 & +77.4 \\
\hline Sum of profits, mln rub. & 883.2 & 1662.5 & 2205.5 & 1019.0 & 1881.2 & +112.9 \\
\hline Selling price, rub. per $1 \mathrm{c}$. & 686 & 787 & 796 & 627 & 800 & +16.6 \\
\hline Prime cost $1 \mathrm{c} .$, rub. & 643 & 687 & 679 & 577 & 715 & +11.2 \\
\hline Return on sales, $\%$ & 8.8 & 12.7 & 14.7 & 7.9 & 10.6 & +1.8 \\
\hline Profitability, $\%$ & 9.9 & 14.6 & 17.2 & 8.7 & 11.9 & +2.0 \\
\hline
\end{tabular}


Table 2 shows that over 2014-2018 the gross grain production and yield grew by 8.7 and $14.8 \%$, respectively. By 2018, 1,132 centners of grain were produced per 100 hectares of tilled area. During the analyzed period, the volume of grain sales made $44.4 \%$, with an increase of 15.1 percentage points. The yield of grain sales in the republic in 2014 amounted to $8.8 \%$, and the profitability of sold products was $9.9 \%$. By 2018, these indicators changed to 10.6 and $11.9 \%$. The current run of the grain market played a stimulating role for grain producers. The problem of grain sale on favorable terms for producers is not yet solved, so it is necessary to intensify the implementation of the main elements of organizational and economic mechanism to increase the efficiency of grain production industry.

In the conditions of the Republic of Tatarstan, the commodity of grain is primarily influenced by the market price. The market price is often greatly influenced by the monopoly effect of bread-receiving and grain-processing enterprises. In case of a favorable forecast for grain crops and gross collections, grain processing enterprises take a wait-and-see position on the market or offer clearly unwarranted low prices for commodity grain. Data on the efficiency of grain production and sale show that if the grain yield is below 20-21 c per 1 ha, then the sale price on the market is formed at a level more or less acceptable for manufacturers. In this case, the grain supply can be increased to $50 \%$ of its production volume. In other cases, a large part of the grain is more profitable to be used for satisfying the internal need, i.e. to use cattle as feed and to form a seed fund.

According to the results of the study, about 25-30\% of the money is received by agricultural organizations of the Republic of Tatarstan from the sale of crop production. Half of proceeds in cash from the sale of crop products are comes from the sale of grain. The increase of the sales of profitable agricultural products is a prerequisite for sustainable financial position of agricultural enterprises. At the same time, the analysis of the state of the grain market shows that not always the increase in the volume of sales leads to an increase in the profit margin. Thus, in the least yielding year 2015 (21 c from $1 \mathrm{ha}$ ) the profit from grain sale in the republic was 1.6 times more than in the most yielding year 2017 (32 c from 1 ha).

Within strategic perspective different state measures shall be aimed at further development of the grain market, achievement of stability of grain production in order to ensure food independence and accessibility of grain products, internal demand of livestock breeding in fodder grain, and population of bread products, creation of state grain resources and formation of export potential, etc. The executive authorities at the federal level shall ensure price, credit, tax and foreign economic policy acceptable to all participants in the grain market [23]. Unfortunately, market conditions are subject to many factors and the selling price can vary significantly within one month (Fig. 1). In high yielding years (for example, in 2017) grain prices within the country fell almost twice, which adversely affected the financial position of grain producers.

Under conditions of high cost of mineral fertilizers, means of plant protection, rising prices for fuel and lubricants, agricultural producers are forced to master resource-saving technologies and limit themselves in terms of renewal and modernization of the main means of production: cereals, tractors, harvesters and agricultural machines. In this regard, the state support in grain production industry shall be directed to further measures for technical re-equipment of the industry and to intervention of grain products in order to prevent sharp price hikes in the market.

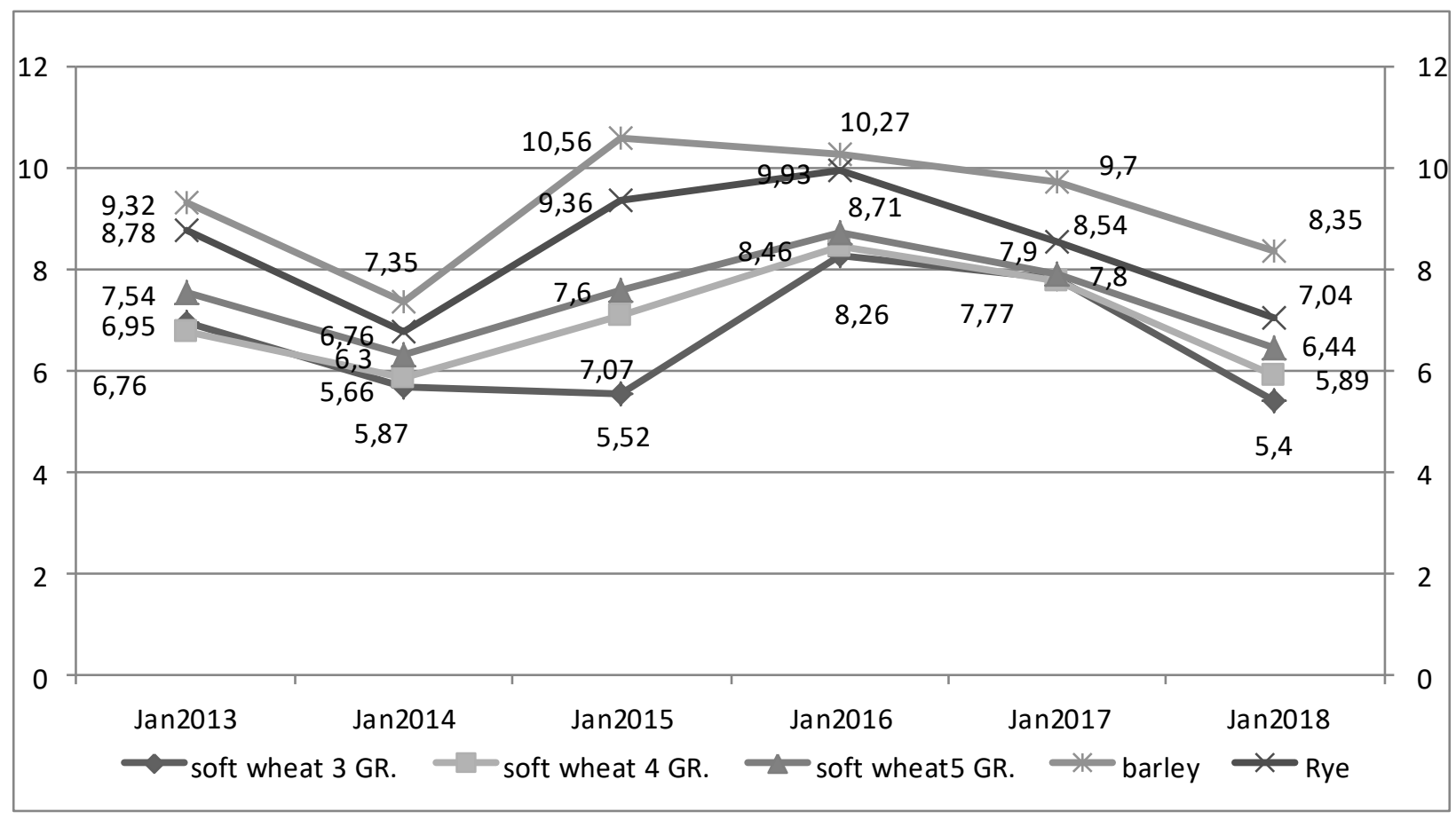

Fig. 1. Dynamics of grain prices in the Russian Federation (price of sale by agricultural producers), thousand rubles per 1 ton 
The factors of agricultural efficiency are divided into four main groups: technological, technical, organizational-economic and social. The most vulnerable factor for grain producers is a group of economic subsystem factors. These include prices for sold agricultural and purchased industrial products, tariffs, loans, taxes, subsidies from the budget, insurance, labor incentives. Another important factor in terms of increasing the culture of agriculture, is the set of factors of the organizational subsystem, including managers and specialists, logistics.

In modern economic conditions, an effective domestic grain market has not yet been fully formed market institutions, competitive environment, logistics systems are not sufficiently developed, there is a search for a rational combination of market mechanisms with the state regulation of domestic grain trade, and conditions for the sale of products have not been created. According to experts every year the grain market of Russia becomes more local due to continuous growth of railway tariffs and increasing share of transport costs in grain price. This is also confirmed by grain realization structure. A significant marketing channel is the regional food fund. Besides, bakery enterprises and elevators of the republic act as sustainable consumers. The presence of grain processing facilities and mill equipment allows processing a certain part of the harvest. In 2017, 265.5 thousand tons of flour, 21.9 thousand tons of cereals and 706.8 thousand tons of mixed fodder were produced by large and medium-sized enterprises. The main areas of implementation occupying an important niche in the regional market include livestock complexes, poultry farms, alcohol industry enterprises. The distribution network is characterized by active activity of intermediaries as the most mobile and adaptable market participants. Local buyers (private intermediaries) sell grain to about $9 \%$ of farms.

When operating in market conditions, it is important for an agricultural producer not only to grow grain, but also to find where to sell it. The studies conducted through a questionnaire survey showed that the majority of producers $(67 \%)$ search for buyers to market commercial grain. Fluctuations in market conditions force rural producers to be more mobile, more determined, to develop and adhere to a certain strategy and tactics of implementation. Due to lack of money for priority payments most farms $(61 \%)$ sell grain in autumn. For the same reason, they are forced to sell grain at any offered prices. At the same time, $28 \%$ of farms adhere to the tactics of waiting for high prices, these enterprises are mainly provided with their grain stores and therefore have the ability to hold grain.

\section{Conclusion}

Based on the results, the following conclusions can be drawn:

1. Establishment of decent, fair, real, economically viable, stable grain prices. Regulation of grain prices by the state, restoration of the state order, implementation of the state order for the reserve grain fund.
2. Improvement of grain marketing routes, expansion of stable sales channels, increase of the number of operators in the republican grain market, formation of an organized distribution channel through the republican commodity exchange for grain sale.

3. Creation of a system of state order by quantity and quality, with specific prices for the next year and the next three years after harvesting, overproduction is an additional cost that is unfavorable for agricultural producers. Production must correspond to demand, for which purpose there must be a state order for a reserve fund.

4. Increase of subsidies for gasoline, oil and lubricants, industrial fertilizers, chemical plant protection, strengthening of state support, concluding contracts with buyers in spring period with prepayment for contract deliveries.

5. Creation of an agency that establishes and controls grain prices and organizes work on grain sale by agricultural business entities not lower than these prices.

\section{References}

1. A. Imangalieva, N. Balashova, Economy of agricultural and processing enterprises 11, 11-14 (2016)

2. M. Zhemdinov, R. Gilfanov, S. Zhemdinov, O. Semicheva, J. of Kazan State Agrarian University 2(44), 98-102 (2017)

3. A. Battalova, O. Ignatjeva, IIOABJ 1, 28-31 (2019)

4. F.N. Mukhametgaliev, L.F. Sitdikova, F.F. Mukhametgalieva, F.N. Avkhadiev, Studies on Russian Economic Development 2, 162-165 (2019)

5. N.F. Kashapov, M.M. Nafikov, M.Kh. Gazetdinov, Sh.M. Gazetdinov, A.R. Nigmatzyanov, IOP Conf. Ser. Mat. Sci. and Engineering 412(1), 012038 (2018)

6. D.I. Faizrakhmanov, Grain Farm of Russia 2, 64-67 (2014)

7. M.-P. Menzel, D. Fornahl, Industrial and Corporate Change 1, 205-238 (2010)

8. A.A. Schutkov, Economics of Agricultural and Processing Enterprises 4, 2-6 (2017)

9. O.V. Kirillova, D.I. Faizrakhmanov, J. of Kazan State Agrarian Univer. 4, 28-30 (2015)

10. I.G. Ushachev, V.V. Maslova, V.S. Chekalin, AIC: economics, management 11, 4-11 (2017)

11. L.V. Mikhailova, Competitiveness in the Global World, Economics, Science 7, part 4 Technologies, 100-103 (2017)

12. I.V. Baranova, E.S. Shevkunova, Grain Farm of Russia 2, 70-72 (2015)

13. D.I. Faizrakhmanov, J. of Kazan State Agrarian Univer. 3, 39-55 (2015)

14. D.F. Khafizov, M.M. Khismatullin, J. of Kazan State Agrarian Univer. 3(50), 157-161 (2018)

15. A.K. Subaeva, A.A. Zamaidinov, Int. Business Management 7, 1780-1784 (2015) 
16. O.V. Kirillova, D.I. Faizrakhmanov, J. of Kazan State Agrarian Univer. 2, 49-53 (2015)

17. I.G. Ushachev, V.V. Maslova, V.S. Chekalin, AIC: Economics, Management 3, 4-12 (2018)

18. L.F. Sitdikova, F.N. Mukhametgaliev, Grain Farm of Russia 2, 68-71 (2014)

19. A.K. Kazybaev, Economics of agricultural and processing enterprises 4, 21 (2015)
20. E.G. Bykov, Economics, labor, agriculture management 4(40), 44-50 (2018)

21. L.A. Molchanova, M.S. Malaya, Competitiveness in the Global World: Economics, Science, Technology 6(56), 68-71 (2017)

22. D.I. Faizrakhmanov, J. of Kazan State Agrarian Univer. 3, 39-55 (2015)

23. O.G. Charykova, D.S. Latynin, Modern Economy: Problems and Solutions 4(64), 138-144 (2015) 